\section{Estimation of Hadronic and EM Resolution for Scintillator Plate Calorimeter Configurations}

P.K. Job and J. Prondfoot

Ifigh Encryy Physics Dirision

Argonne Nalional Lab

9700 S. Cass Ale. Argonne. IL 604:39

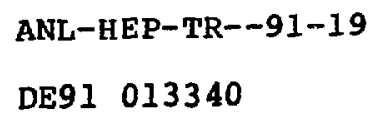

DE91 013340

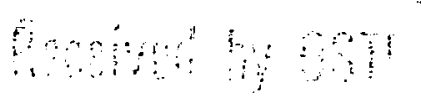

lilhl in ind

\title{
Introduction
}

('AlORS9 Simulation code has been used to estimate the liadronic and chrctromagnetic resolutions for the various scintillator plate calorincter confignrations. The goal of this study was to determine the optimum combinalion of lead and lron based calorimeter, which retajus compensation and lincarily: The configurations considered are Lead/Scintillator and Fe/Scintillator and their combinations. Ultimately: we hope to test these configmations in the langing file beam test at Fermilab in this spring.

\section{Analysis}

This study was carried out for mainly 10 GeV incident pions and clectrons (calculations at higher energies for a limited number of geometries are in progress and will be the subject of a later note). The latera] dimensions of the geometry chosen for this study were $200 * 200 \mathrm{~cm}^{2}$. Earlier calculations have shown that this results in essentially $100 \%$ lateral contaimment of hadronic showrs. For ease in comparison with the earlier work, we have closen to simulate alssorlucr plate thicknesses of $0.56 \mathrm{~cm}$ and $1.0 \mathrm{~cm}$ for Lead and $1.75 \mathrm{~cm}$ for Iron with scintillator plates of $.25 \mathrm{~cm}$. Ouly statistical errors are indicated in thro following results. A detailed sturly of systematies in the ('ALOR simulation is in progress. Presently we estimate the largest systematic unkmowns at +5"y from the rollision model and $\pm 4 \%$ from the saturation properies of the scintillates.

Table I gives the sumbuary results of electronagnetic resolulions for the

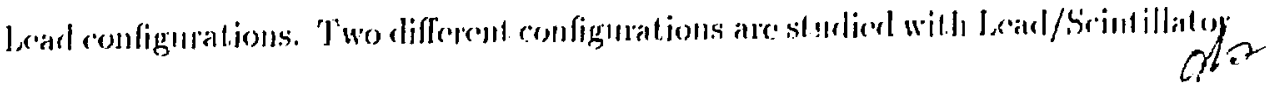


ratios of approximately 2 and 1 . In the coarse sampling configurat ion the lish resolution is degraded by a factor slightly more than the rat io of the scpare root of the alssorber thicknesses. The resolution worsens by $5 \%$ lor the pserulo rapidjty of 1.5 in funer sampling calorimeters. This effect is $10 \%$ in coarse sampling configuralions.

Table II gives the IIadronic resolutions for three different Lead configmalions, will Lead/Scintillator ralio $.56 / .25$ and $1.00 / .25$ and for a conlsined system comprising an ENI calorineter with fine sampling and the hadronic section with coarse sampling. For the latter geometry the signal from the hadronic section is weighted by the ratio of the alssorber thicknesses. In this case the simple weighting by $(\mathrm{dE} / \mathrm{d} X) \Delta X$ sampling is rery effeclive and the resolution is degraded by only a few \% compared to a fune sampling svistem. This justifies a calibration scheme by mips. As is observed in the single geometries, the resolution worsens by approximately the square root of the sampling Whicliness at a pseudo rapidity of 1.5 .

Table III and Figure 1 give the summary results for the Lead-lron configurations. The resolution and $\mathrm{e} / \mathrm{h}$ of the combined system was calculated as the function of the location in depth of the Lead-iron boundary. Figure 2 gives the fractional energy in the Iron/scintillator module as a funclion of Lead/Scintillator thickness for these configuralions. It can be spen that the fractional energy in the lron section is siguificant upto a Lead calorimeter thickness of $4 \lambda$.

Three relative weighting sclomes were used to match the iron to the learl respouse:

1. by the calculated (tI/dX) for the unit cell in the Lead ant Joon stacks.

2. by the ratio of the ECis simulated e/mip) ralue for both sections.

3. by using an arbilary weight factoc which forces $e / h=1$.

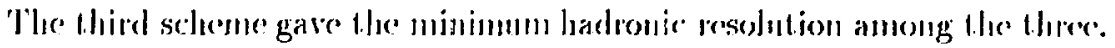


The results show that this weight ing fact or is independent of the conliguration. The correction in the weighting factor relative to the simple ( $\mathrm{dE} / \mathrm{dX}$ ) schemo is only $15 \%$. Br this weighting schene the configuration with th head and th Iron has a hadronic resolution very close to a pure Lead/Scintillalor system. The corresponding resolution for a system comprising of $1 \lambda$ Lead calorimenter (Lead EMI section only) backed by the Fe/Scin section is about. 25\% worse.

The linearity of one of the configurations ( $1, \lambda$ Lead and $4 \lambda$ Iron) is being investigated with the optimum weighting scheme. So far 10 and 30 Gief pions have been simulated. Table IV give the preliminary results of this simulation. The linearity of response is good within $1 \%$ which is close to the statislical error in these calculations. We are planning to simulate 70 GeV pions whir.l will strain our computing resources.

\section{Conclusions}

CALOR simulation results for 10 Gel inciclent pions show that a macroscopic calorimeter geometry of $4 \lambda$ of Lead in a compensating configutalion followed by $4 \lambda$ of Iron with moderate sampling is essentially as compensating as a purcly Lead compensating calorincter. Within the errors of this calculation the relative weight of Iron to Lead response used to obtain this result: is inclependent of the fraction of depth (and energy drposition) of the fron system. Therefore it is hoped that this weight will also be independent of the incident energy. Data from the first of the higher encrgy points indicate that the above rleduction is indeed correct.

Work supported in part by the U.S. Department of Energy, Division of High Energy Physics, Contract W-31-109-ENG-38. 


\section{Table I}

\section{EM RESOLUTION FOR LEAD CONFIGURATIONS}

\begin{tabular}{|c|c|c|c|c|}
\hline ('onliguration & $\begin{array}{l}\text { Energy } \\
\text { (GeV) }\end{array}$ & $\begin{array}{l}\text { Thick. } \\
\lambda\end{array}$ & $\eta$ & $\begin{array}{l}\text { EM Reso. } \\
(\%)\end{array}$ \\
\hline EMC: $.56 / .25 \mathrm{~cm}$ & 10.0 & 1 & 0. & $5.31 \pm 0.70$ \\
\hline EMC $.56 / .25 \mathrm{~cm}$ & 10.0 & $1 \cos \theta$ & 1.5 & $6.98 \pm 0.78$ \\
\hline ENIC: $.56 / .25 \mathrm{~cm}$ & 30.0 & 1 & 0. & $3.42 \pm 0.46$ \\
\hline ENIC $1.0 / .25 \mathrm{~cm}$ & 10.0 & 1 & 0. & $7.42 \pm 0.73$ \\
\hline $\operatorname{ENC}^{\prime} 1.0 / .25 \mathrm{~cm}$ & 10.0 & $1 \cos \theta$ & 1.5 & $11.21 \pm 0.75$ \\
\hline
\end{tabular}

\section{DISCLAIMER}

This report was prepared as an account of work sponsored by an agency of the United States Government. Neither the United Stutes Government nor any agency thereof, nor any of their employees, makes any warranty, express or implied, or assumes any legal liability or responsibility for the accuracy, completeness, or usefulness of any information, apparatus, product, or process disclosed, or represents that its use would not infringe privately owned rights. Reference herein to any specific commercial product, process, or service by trade name, trademark, manufacturer, or otherwise does not necessarily constitute or imply its endorsement, recommendation, or favoring by the United States Government or any agency thereof. The views and opinions of authors expressed herein do not necessarily state or reflect those of the United States Government or any agency thereof. 
Table II

HADRONIC RESOLUTION AND e/h RATIO

FOR LEAD CONFIGURATIONS (10 $\left.\mathrm{GeV} \pi^{-}\right)$

\begin{tabular}{|c|c|c|c|c|}
\hline Configuration & $\begin{array}{l}\text { 'Thick. } \\
\lambda\end{array}$ & $\eta$ & e/h Ratio & $\begin{array}{l}\text { Ilad.lReso. } \\
(\%)\end{array}$ \\
\hline $\begin{array}{l}\text { EAC: } .56 / .25 \mathrm{~cm} \\
H A C: .56 / .25 \mathrm{~cm}\end{array}$ & $\begin{array}{l}1 \\
i\end{array}$ & 0. & $0.99 \pm .01$ & $9 . \overline{7} \pm 0.70$ \\
\hline $\begin{array}{l}\text { ENIC: } 1.0 / .25 \mathrm{~cm} \\
H \Lambda C: 1.0 / .25 \mathrm{~cm}\end{array}$ & $\begin{array}{l}1 \\
T\end{array}$ & 0. & $0.95 \pm .01$ & $12.1 \pm 0.75$ \\
\hline $\begin{array}{l}\text { ENC: } .56 / .25 \mathrm{~cm}^{(0)} \\
\text { HAC } 1.0 / .25 \mathrm{~cm}\end{array}$ & $\begin{array}{l}1 \\
7\end{array}$ & 0. & $0.98 \pm .01$ & $11 . \pm \pm 0.75$ \\
\hline $\begin{array}{l}\mathrm{EMC}: .56 / .25 \mathrm{~cm}^{(a)} \\
\text { IIAC } 1.0 / .25 \mathrm{~cm}\end{array}$ & $\begin{array}{l}1 \cos \theta \\
\pi \cos \theta\end{array}$ & 1.5 & $0.95 \pm .01$ & $19.8 \pm 0.75$ \\
\hline
\end{tabular}

(a) Signal from HAC section is weighted by a factor $1.0 / .56$ 
Table III

HADRONIC RESOLUTION AND e/h RATIO

FOR LEAD-IRON CONFIGURATIONS (10 GeV $\left.\pi^{-}\right)$

$\mathrm{Pb} / \mathrm{SCIN}=0.56 / 0.25 \mathrm{~cm}, \mathrm{Fe} / \mathrm{SCIN}=1.75 / 0.25 \mathrm{~cm}$

\begin{tabular}{|c|c|c|c|c|c|}
\hline Configutation & & $\begin{array}{l}\text { Simple } \\
\text { Sim }\end{array}$ & $\begin{array}{l}(d E / d X) \triangle X \\
\text { Weighting }\end{array}$ & $\begin{array}{l}\text { EM(! ('ali. } \\
\text { Correction wrt. } \\
(\mathrm{dE} / \mathrm{dX}) \text { weight.g } \\
=0.715\end{array}$ & $\begin{array}{l}\mathrm{e} / \mathrm{h}=\mathrm{I} .00 \\
\text { Correction wht. } \\
(\mathrm{dE} / \mathrm{dX}) \text { weightg } \\
=0.8 .16\end{array}$ \\
\hline$P b s \lambda$ & $\begin{array}{l}\text { e/li } \\
\text { Reso. }\end{array}$ & $\begin{array}{l}0.99 \pm .02 \\
9 . \overline{1} \pm .7 .5\end{array}$ & & & \\
\hline $\mathrm{Pb} 6 \lambda, \mathrm{Pe} 2 \lambda$ & $\begin{array}{l}\text { e/h } \\
\text { Reso. }\end{array}$ & $\begin{array}{l}0.99 \pm .02 \\
11.2 \pm .75\end{array}$ & $\begin{array}{l}1.00 \pm .0 \\
11.1 \pm .78\end{array}$ & $\begin{array}{l}1.01 \pm .02 \\
11.0 \pm .77\end{array}$ & $\begin{array}{l}1.00 \\
10.5 \pm .75\end{array}$ \\
\hline $\mathrm{Pl}, t \lambda, \mathrm{Fe} 4 \lambda$ & $\begin{array}{l}\text { e/h } \\
\text { Reso. }\end{array}$ & $\begin{array}{l}1.03 \pm .02 \\
13.6 \pm .75 \\
\end{array}$ & $\begin{array}{l}0.98 \pm .02 \\
11.2 \pm .78\end{array}$ & $\begin{array}{l}1.00 \pm .02 \\
10.6 \pm .77 \\
\end{array}$ & $\begin{array}{l}1.00 \\
10.5 \pm .75\end{array}$ \\
\hline $\mathrm{Pl} 2 \lambda$, Fe $6 \lambda$ & $\begin{array}{l}\text { e/h } \\
\text { Reso. }\end{array}$ & $\begin{array}{l}1.26 \pm .02 \\
23.3 \pm .75 \\
\end{array}$ & $\begin{array}{l}0.94 \pm .02 \\
14.1 \pm .35 \\
\end{array}$ & $\begin{array}{l}1.06 \pm .02 \\
12.0 \pm .75 \\
\end{array}$ & $\begin{array}{l}1.00 \\
12.0 \pm .75\end{array}$ \\
\hline $\mathrm{P} b 1 \lambda, \mathrm{Fe} i \lambda$ & $\begin{array}{l}\text { e/h } \\
\text { Reso. }\end{array}$ & $\begin{array}{l}1.65 \pm .02 \\
2 \pi .3 \pm .75\end{array}$ & $\begin{array}{l}0.90 \pm .02 \\
14.5 \pm .80\end{array}$ & $\begin{array}{l}1.12 \pm .02 \\
13.0 \pm .77\end{array}$ & $\begin{array}{l}1.00 \\
12.9 \pm .75\end{array}$ \\
\hline Pe $8 \lambda$ & $\begin{array}{l}\text { e/h } \\
\text { Reso }\end{array}$ & $\begin{array}{l}1.19 \pm .02 \\
17.5 \pm .75\end{array}$ & & & \\
\hline
\end{tabular}




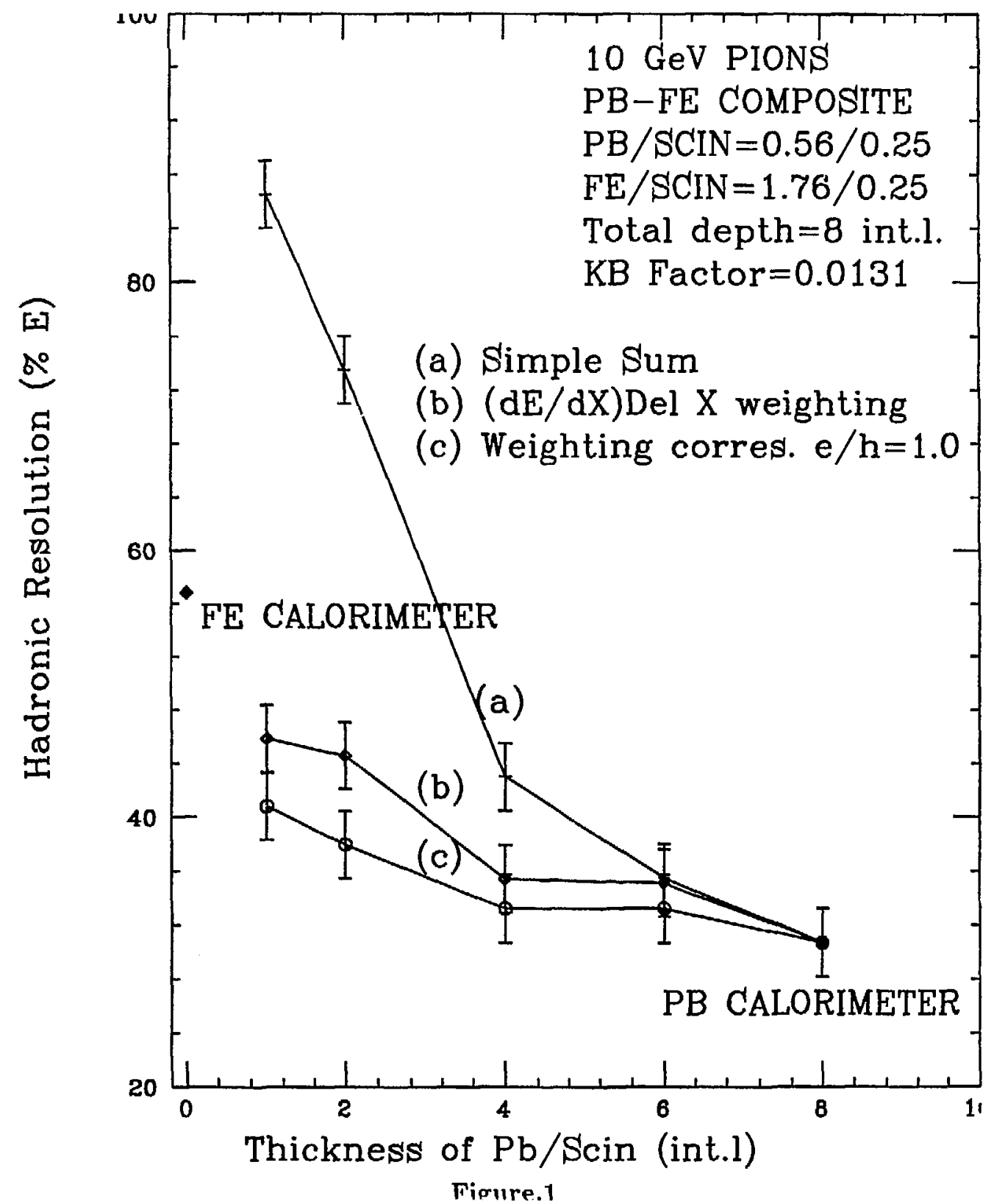




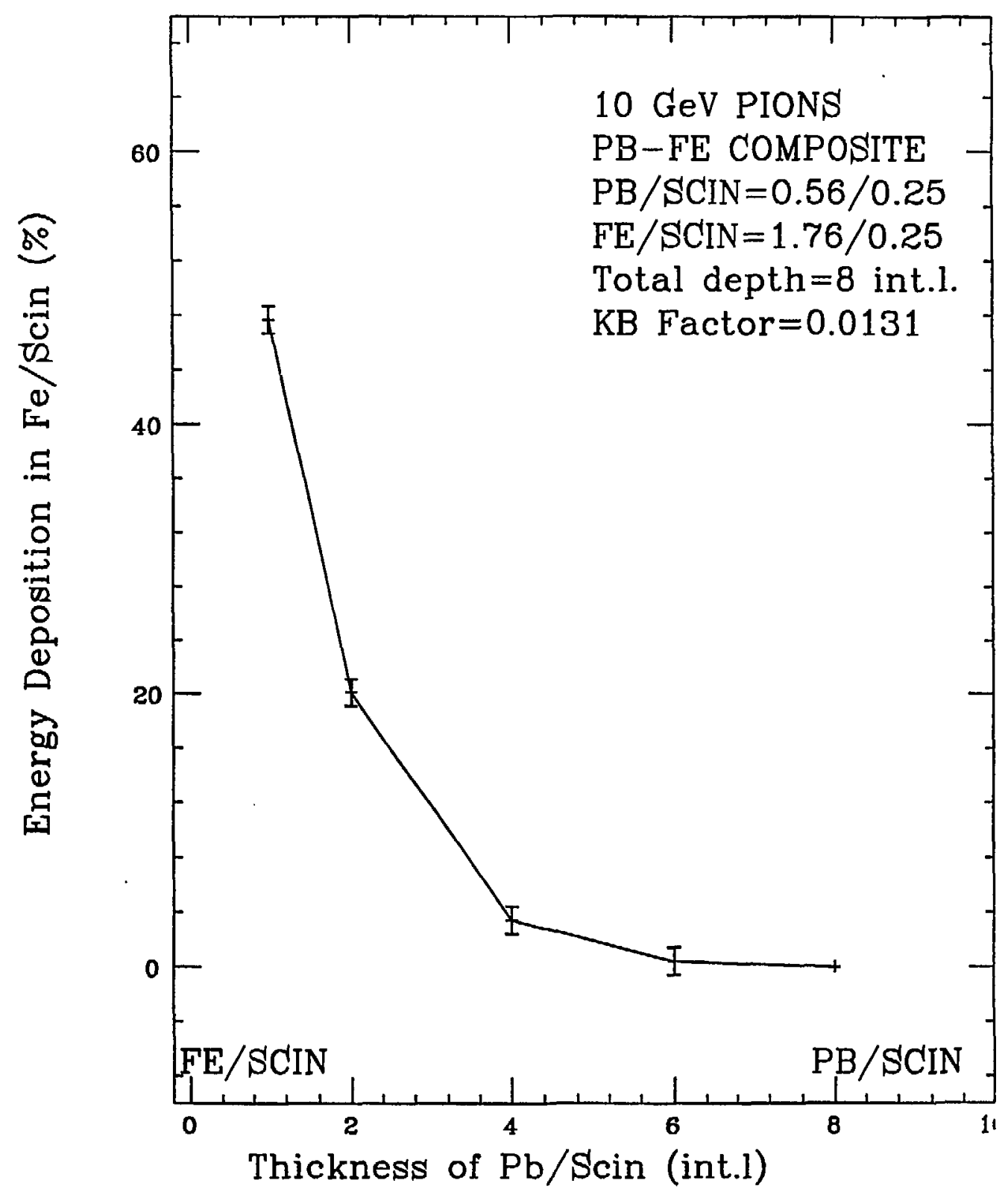


Table IV

LINEARITY OF LEAD-IRON CONFIGURATIONS

$\mathrm{Pb} / \mathrm{Scin}=0.56 / 0.25 \mathrm{~cm}, \mathrm{Fe} / \mathrm{Scin}=1.75 / .25 \mathrm{~cm}$

$\mathrm{Pb} / \mathrm{scin}=4 \lambda, \mathrm{Fe} / \mathrm{Scin}=4 \lambda$

\begin{tabular}{|l|l|l|l|}
\hline Energy & Iladrons & \multicolumn{2}{|c|}{ Rel. Sigual/GeV } \\
\cline { 3 - 4 }$\left(\right.$ GeV $^{(1)}$ & Reso.(\%) & Elec.Mlag. & Hadionic $^{(1)}$ \\
\hline 10.00 & 10.50 & 4.007 & 4.025 \\
& & & \\
\hline 30.00 & 8.23 & 3.951 & 3.931 \\
\hline 75.00 & & & \\
\hline
\end{tabular}

(1) Oplinum weighting $(\mathrm{e} / \mathrm{h}=1.00)$ 